\title{
Obesity and abdominal wound healing in rats $^{1}$
}

\author{
Obesidade e cicatrização da parede abdominal em ratos
}

\author{
Maria de Lourdes Pessole Biondo-Simões ${ }^{\mathrm{I}}$, Guilherme Roberto Zammar ${ }^{\mathrm{II}}$, Rodrigo dos Santos Fernandes ${ }^{\mathrm{III}}$, Rachel Biondo- \\ Simões ${ }^{\text {III }}$, Flavia Stica Ritzdorf de Mello"II, Lucia de Noronha ${ }^{\text {IV }}$ \\ ${ }^{I} \mathrm{PhD}$, Full Professor, Scientific Methodology, PUCPR and Associate Professor, Department of Surgery, Federal University of Paraná (UFPR), Brazil. \\ ${ }^{\text {II }}$ Graduate Student, Scientific Initiation Program, PUCPR and CNPq scholarship holder, Parana, Brazil. \\ III Graduate Student, Scientific Initiation Program, PUCPR, Parana, Brazil. \\ Iv PhD, Full Professor, Division of Pathology, PUCPR and Associate Professor, Division of Pathology, UFPR, Parana, Brazil.
}

\begin{abstract}
Introduction: Treatment for obesity essentially has to do with weight loss, which can be achieved through surgical procedures. Despite the considerable rise in the number of such procedures, the relationship between obesity and the healing process has not been totally clarified. Purpose: To investigate abdominal wound healing in obese Wistar rats on the seventh and fourteenth days following a laparotomy. Methods: Thirty-six Wistar rats were randomly distributed into two groups, the control and experiment group. The control group were fed on either a standard diet for the species and the experiment group were put on a high calorie diet. After 116 days, all the animals were submitted to a laparotomy followed by laparorrhaphy. After euthanasia on the seventh or fourteenth day, fragments of the abdominal wound containing the scar were submitted to histopathological and tensiometric analysis. Results: The average weight of the animals from the experiment group was higher than that of the control group $(p<0.001)$. The difference in the resistance of the cutaneous scars was not significant. The aponeurotic scars were more resistant in the control group after seven days $(p=0.011)$ and fourteen days $(\mathrm{p}=0.040)$. There was no difference in terms of intensity of the inflammatory reaction and the collagen density was similar in both groups. Conclusion: In rats, obesity lowered the resistance of the aponeurotic scars but not the skin scars. It did not interfere with the delayed inflammatory response and the collagen density.
\end{abstract}

Key words: Wound Healing. Obesity. Collagen. Rats.

\section{RESUMO}

Introdução: O tratamento da obesidade é baseado essencialmente na perda de peso, e isto pode ser conseguido por meio de procedimentos cirúrgicos. Apesar do grande aumento no número destes procedimentos, a relação entre obesidade e o processo de cicatrização ainda não está totalmente elucidada. Objetivo: Investigar a cicatrização da parede abdominal de ratos Wistar obesos, sete e 14 dias após laparotomia. Métodos: Ratos Wistar, em número de 36 foram alocados em dois grupos, controle e experimento. Os do grupo controle receberam dieta padrão para a espécie e os do experimento dieta hipercalórica. Depois de 116 dias, todos os animais foram submetidos à laparotomia seguida de laparorrafia. Após a eutanásia com sete ou 14 dias, fragmentos da parede abdominal contendo a cicatriz receberam análise histopatológica e tensiométrica. Resultados: O peso médio dos animais do grupo experimento foi maior do que o do grupo controle $(\mathrm{p}<0,001)$. A diferença da resistência das cicatrizes cutâneas não foi significante. As cicatrizes aponeuróticas foram mais resistentes no grupo controle aos sete dias $(p=0,011)$ e aos 14 dias $(p=0,040)$. Não houve diferença quanto à intensidade da reação inflamatória e a densidade de colágeno foi semelhante nos dois grupos. Conclusão: Em ratos, a obesidade diminuiu a resistência das cicatrizes aponeuróticas, mas não a das cicatrizes da pele. Não interferiu na reação inflamatória tardia e nem na densidade do colágeno.

Descritores: Cicatrização de Feridas. Obesidade. Colágeno. Ratos.

${ }^{1}$ Research performed at Division of Research Methodology, Pontific Catholic University of Parana (PUCPR), Brazil.

\section{Introduction}

The World Health Organization (WHO) defines obesity and overweight as an excessive or abnormal accumulation of body fat that can be harmful to a person's health. Overweight means that the body mass index (BMI) is equal to or over $25 \mathrm{~kg} / \mathrm{m}^{2}$, and obesity means that the BMI is equal to or over $30 \mathrm{~kg} / \mathrm{m}^{2}$. The latest global projections of the WHO for obesity estimate that there are approximately 1.6 billion adults who are overweight, and at least 400 million are obese. The organization expects that in 2015 
around 2.3 billion adults will be overweight and at least 700 million will be obese ${ }^{1}$. Although it used to be viewed as a problem in developed countries, the obesity and overweight rates have been growing dramatically in developing countries too, especially in urban areas. Obesity and overweight can lead to a number of consequences for people's health, such as cardiovascular disease (principally coronary heart disease), diabetes mellitus, muscle and bone diseases (especially osteoarthritis) and some types of cancer (especially colon, breast and endometrial cancer) ${ }^{1}$.

The aim of obesity treatment is weight loss, which leads to reduced insulin resistance, better control of diabetes mellitus, lower blood pressure, an improved lipid profile and, consequently, reduced risk of cardiovascular disease ${ }^{2}$. Studies have shown disappointing results for the conservative treatment of obesity in the long term, while there is evidence in the literature that surgical treatment of obesity can lead to more sustainable weight loss in selected patients ${ }^{3}$. Although there have been accurate indications and satisfactory results, there are considerable complications when obese or overweight patients are submitted to surgery, with incisional hernias being one of the most common delayed complications $^{4,8}$. This is because of deficient healing of the muscular-aponeurotic stratum or increased intra-abdominal pressure ${ }^{5,9}$. Concerning the relationship of these two factors with obesity, some authors have reported a hernia in obese patients with increased intra-abdominal pressure and without any healing deficiency ${ }^{5,10}$. Healing deficiency has been related to factors such as surgical wound infection, malnutrition, technical failure, considerable blood loss, and others ${ }^{11}$. Several authors have recognized that obesity hinders the healing process in a number of types of tissue $\mathrm{e}^{12-14}$. Operations to repair incisional hernias range from simple syntheses to prosthesis. Sauerland et al. ${ }^{15}$. report that obesity is an important factor in the repair of incisional hernias. They observed a relative risk of 1.51 with a confidence interval of $95 \%$ between 0.5 and 4.2 ( $\mathrm{p}=0.03$ ). Concerning the healing of the abdominal wound, Nascimento et al. ${ }^{14}$ analyzed cutaneous wounds from Wistar rats in detail and concluded that the obesity induced by a hyperlipid diet had a negative effect on the healing as it prolonged the inflammatory phase. The authors did not analyze the muscular-aponeurotic layer of the abdominal wound, which plays a fundamental role in the physiopathology of the incisional hernia. The excess of adipose tissue, which is known to play an endocrinal role ${ }^{16,17}$, could have a negative impact on the healing process of the abdominal wound, although little information about this is available.

The aim of this study is to analyze experimentally the healing of the abdominal wound of Wistar rats with induced obesity seven and fourteen days after a median laparotomy.

\section{Methods}

The project which originated this study was submitted for analysis by the Ethics Committee on the Use of Animals at the PUC University of Paraná and approved and allocated number 318-2008. The research was carried out within the guidelines of the Brazilian College of Animal Experiments (COBEA) and Federal Law 11.794.

Thirty-six male Wistar rats (Rattus norvegicus albinus, Rodentia mammalia) aged between 100 and 130 days and weighing between 246 and $332 \mathrm{~g}$ were used. They were brought from the animal colony of the university and were randomly separated into two groups of $18(\mathrm{E}=$ experiment group and $\mathrm{C}$ $=$ control group). They were kept at the animal colony, where the macro-environment is semi-controlled, with a light period of twelve hours, average room temperature of $20 \pm 2^{\circ} \mathrm{C}$. The noise intensity and the relative humidity are those of the general environment. All the cages were placed at the same distance from the light source. The animals had free access to water and food throughout the experiment.

The animals in group E were offered the high calorie diet of Levin et al. ${ }^{18}$. This diet consists of $8 \%$ corn oil, $44 \%$ condensed milk and $48 \%$ industrial feed. The industrial feed in this case was Nuvilab CR $1^{\circledR}$ bran. The mixture was formed into pellets in order to make them similar to the standard feed for the species. It was placed in the microwave oven for 3 to 5 minutes to give it a solid consistency. The group $\mathrm{C}$ animals were given standard feed for the species (pellet-shaped Nuvilab CR $1^{\circledR}$ ).

The surgical procedure took place 116 days after the diet was begun. In the 24 hours leading up to the surgery, the animals were given only water. Under an anesthetic of $0,2 \mathrm{ml} / 100 \mathrm{~g}$ of weight of the mixture of one milliliter of ketamine $(50 \mathrm{mg} / \mathrm{ml})$ with a milliliter of xylazine $(20 \mathrm{mg} / \mathrm{ml})$ the rats were weighed again. The animals were submitted to trichotomy of the ventral abdominal wall and antisepsis with $1 \%$ polyvinylpyrrolidone-iodine. A $4 \mathrm{~cm}$ median laparotomy was performed with two continuous synthesis planes: the first peritoneal-musucular-aponeurotic, the second of the skin, with 3-0 nylon monofilament thread. After recovering from the anesthetic, the animals were returned to their cages, where they continued to follow their diet according to their group. At this stage, nine rats were selected from group $\mathrm{C}$ to be submitted to euthanasia after seven days (C7 and E7). The others were submitted to euthanasia after fourteen days (C14 and E14). For euthanasia, they were given a lethal dose of intraperitoneal sodium tyopenthal $(150 \mathrm{mg} / \mathrm{kg})^{19,20}$.

A $6 \times 4 \mathrm{~cm}$ fragment of the ventral abdominal wound containing the skin scar and the muscular-aponeurotic stratum was removed. This fragment was cut transversally in half, and these parts were called Fragment P (proximal) and Fragment D (distal). The first proximal centimeter of fragment $P$ was discarded, and the last distal centimeter was discarded from Fragment D.

The tensile strength of the $\mathrm{P}$ fragments were analyzed by an $\mathrm{EMIC}^{\circledR}$ tensiometer, model $5 \mathrm{kN}$. Forces were applied, always perpendicular to the scar, in an attempt to separate its edges at a speed of $25 \mathrm{~mm} / \mathrm{min}$. The maximum strength was considered to be the greatest force or charge applied to the body until it ruptured.

The D fragments were set in $10 \%$ formalin solution and were used for the histopathological analysis. The histological cuts, four micrometers thick, were stained with hematoxylin-eosin and Sirius Red. The following parameters were analyzed: inflammatory reaction, fibrosis and collagen ordering. These parameters were qualitatively classified as: absent, discrete, moderate and intense.

The cuts treated with Sirius Red staining were analyzed, having been magnified 200 times, using an Olimpus ${ }^{\circledR}$ BX-50 optical microscope with polarized light. In this staining, the thicker and highly birefringent collagen fibers are collagen I, and are colored red and yellow, and the thinner, less concentrated and more weakly birefringent collagen III fibers are greenish in hue. The images were obtained using a Sony ${ }^{\circledR}$ CCDIRIS camera, which were transmitted to a Dell monitor and analyzed using Image Pró- 
Plus ${ }^{\circledR} 4.0$ for Windows on an Intel Pentium 4 computer. The percentages occupied by type I and III fibers were analyzed and calculated, and thus an average of the reading of each cut was obtained.

The results obtained were expressed as averages, standard deviations, medians, minimum and maximum values or frequencies and percentages. For comparison of the groups in relation to quantitative variables, the Student $t$ test was used for independent samples, or the non-parametric Mann-Whitney test was used. For parametric values, the student- $t$ test was used. Values of $p<0.05$ indicated statistical significance. The data were organized on an Excel flowchart and analyzed with the help of the Statistic 8.0 computer program.

\section{Results}

In the fifth week of the diet, one of the Group $\mathrm{C}$ rats died for no apparent reason. During the surgery, two Group E rats and one Group $\mathrm{C}$ rat died due to an anesthetic accident. The sample was reduced to sixteen rats in each group.

The average weight of the rats at the beginning of the study was $280.13 \pm$ $23.16 \mathrm{~g}$ for the control group and $291.88 \pm$ $23.06 \mathrm{~g}$ for the experiment group $(\mathrm{p}=0.155)$. After 116 days, the control group rats weighed $390.19 \pm 24,36 \mathrm{~g}$ and the experiment group weighed $458.00 \pm 33.18 \mathrm{~g}$ $(\mathrm{p}<0.001)$.

The scar resistance analysis showed that the maximum average force was $3.17 \pm 2.63 \mathrm{~N}$ for Group $\mathrm{C}$, and $4.48 \pm$ $1.81 \mathrm{~N}$ for Group $\mathrm{E}$, after 7 days $(\mathrm{p}=0.130)$. After 14 days, the resistance was $5.73 \pm 1.91 \mathrm{~N}$ for Group C, and 4.75 $\pm 1.52 \mathrm{~N}$ for Group $\mathrm{E}$ $(p=0.463)$. The skin scars from Group C were more resistant after 14 days than after 7 days ( $p=0.014)$. In Group E, there was no significant difference after 7 days and after 14 days $(\mathrm{p}=0.721)$ (Figure 1$)$.

Analysis of the resistance of the aponeurotic scars showed that the average maximum force for Group $\mathrm{C}$ was $13.57 \pm$ $4.23 \mathrm{~N}$ and $8.54 \pm 2.77 \mathrm{~N}$ for Group $\mathrm{E}$, after 7 days $(\mathrm{p}=0.011)$. After 14 days, this value was $15.38 \pm 3.23 \mathrm{~N}$ for Group C and 11.81 $\pm 2.68 \mathrm{~N}$ for Group $\mathrm{E}(\mathrm{p}=0.040)$. The aponeurotic scars of the Group E rats were more resistant after 14 days than after 7 days $(p=0.007)$. In Group $C$ there was no significant difference after 7 and after 14 days $(\mathrm{p}=0.721)$ (Figure 2$)$.

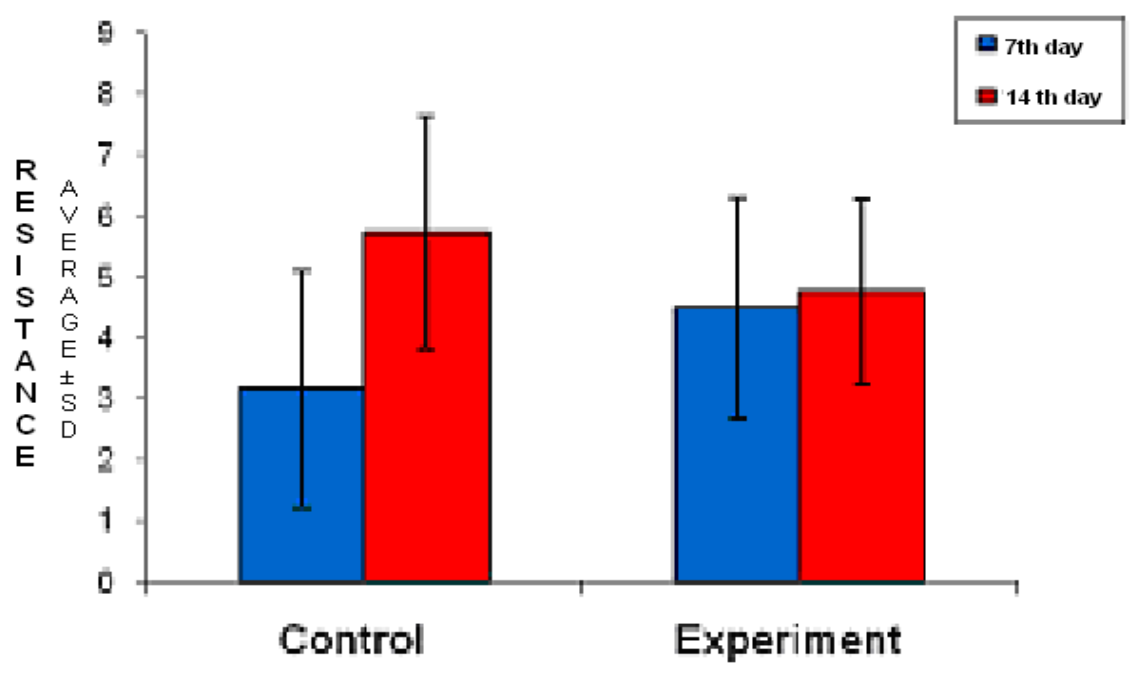

FIGURE 1 - Average resistance (Newtons) of the skin scars on the 7th and 14th days

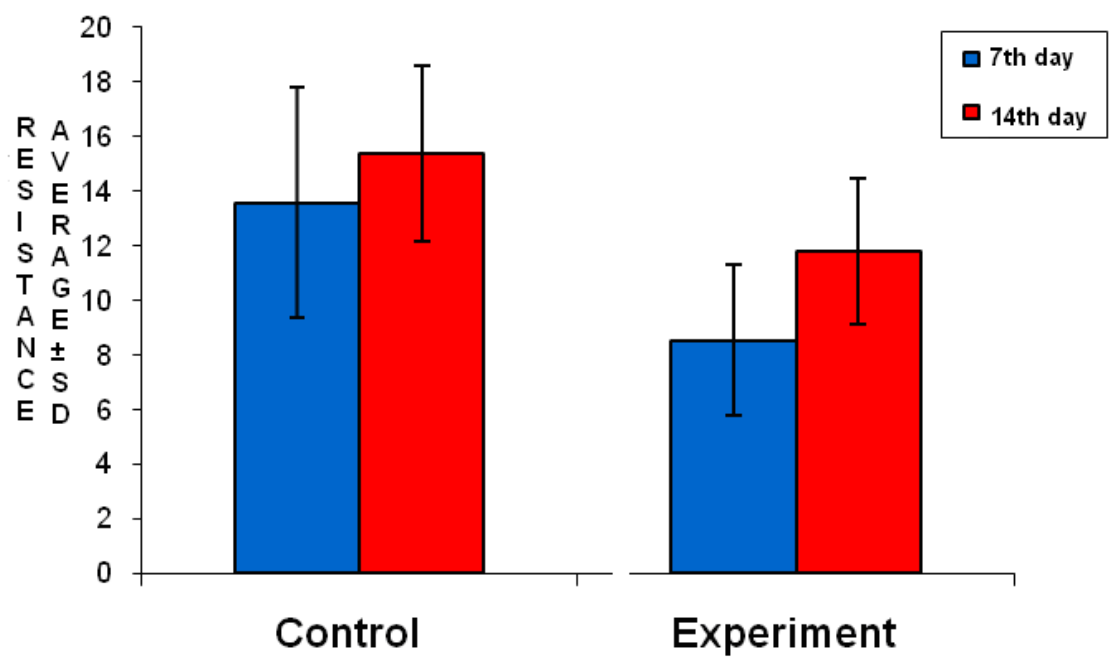

FIGURE 2 - Average resistance (Newton) of aponeurotic scars on the 7th and 14th days 
The histological examination showed that the inflammatory reaction in the skin was predominantly intense on the seventh day in both groups, with no difference between them $(p=0.206)$, and discretely to moderately intense after fourteen days $(p=1.000)$. This reaction in the aponeurosis was of moderate intensity on both occasions, with no difference on the seventh day $(\mathrm{p}=1.000)$ or the fourteenth day $(\mathrm{p}=0.077)$.

Collagen density analysis in the skin examined after seven days showed no differences in the amount of type I collagen $(p=0.743)$ and total collagen $(p=0.167)$. Group $E$ had on average $24.29 \%$ of type III collagen, and Group C had on average $11.35 \%$ $(\mathrm{p}=0.004)$ (Figure 3).

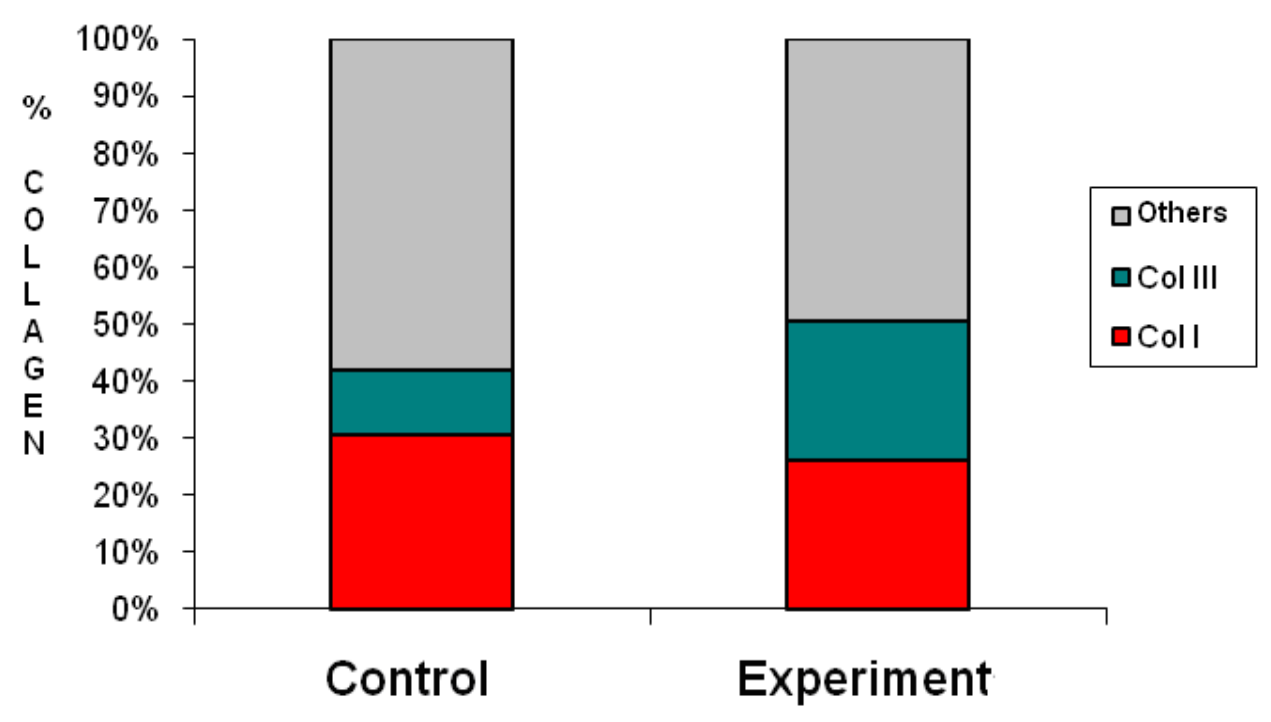

FIGURE 3 - Collagen density found in the skin scars on the 7th day

After 14 days, there was no difference between the two and type III $(\mathrm{p}=0.094)$ (Figure 4). groups concerning total collagen density $(p=0.463)$, type $I(p=0.397)$

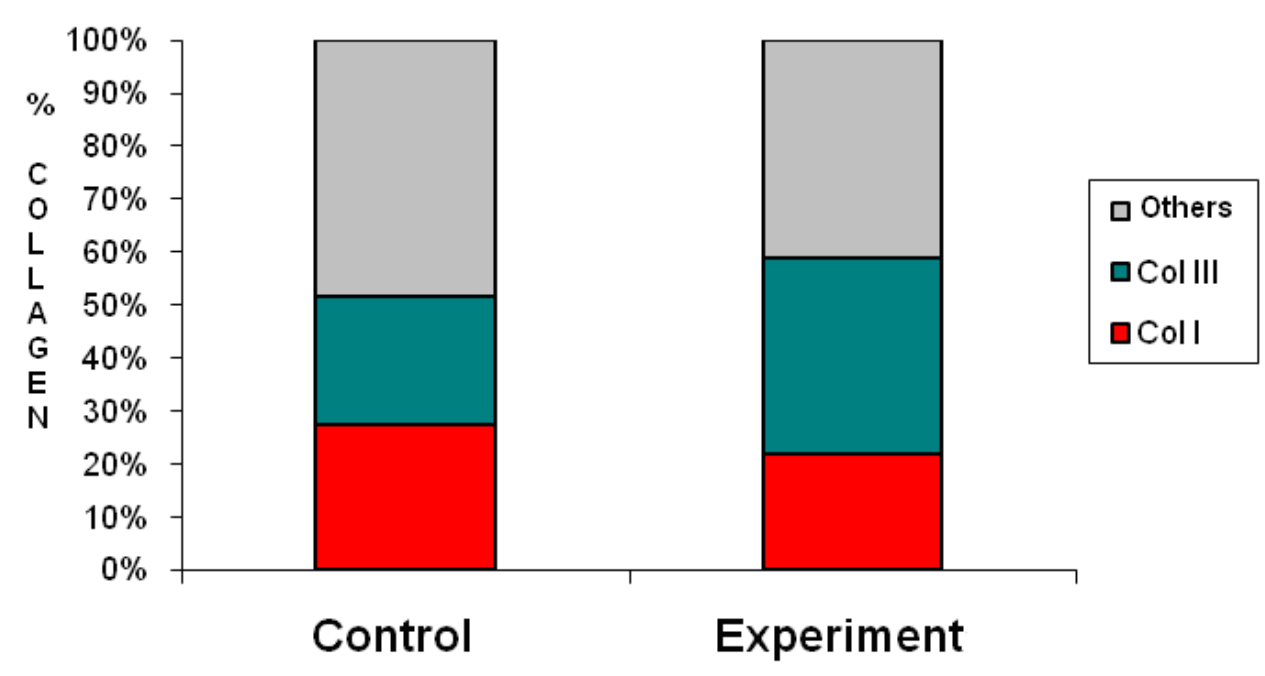

FIGURE 4 - Collagen density found in the skin scars on the14th day 
When the results for the seventh and fourteenth days are compared, the skin scars of both groups showed a higher amount of type III collagen after 14 days than after 7 days (Group E, $p=0.021$ ; Group $\mathrm{C}, \mathrm{p}=0.021$ ), although there was no difference between type I and total collagen.

The collagen analysis in the aponeurosis after seven days showed no significant difference in the amount of type $I(p=0.195)$, type III $(p=0.789)$ and total collagen $(p=0.234)$ (Figure 5).

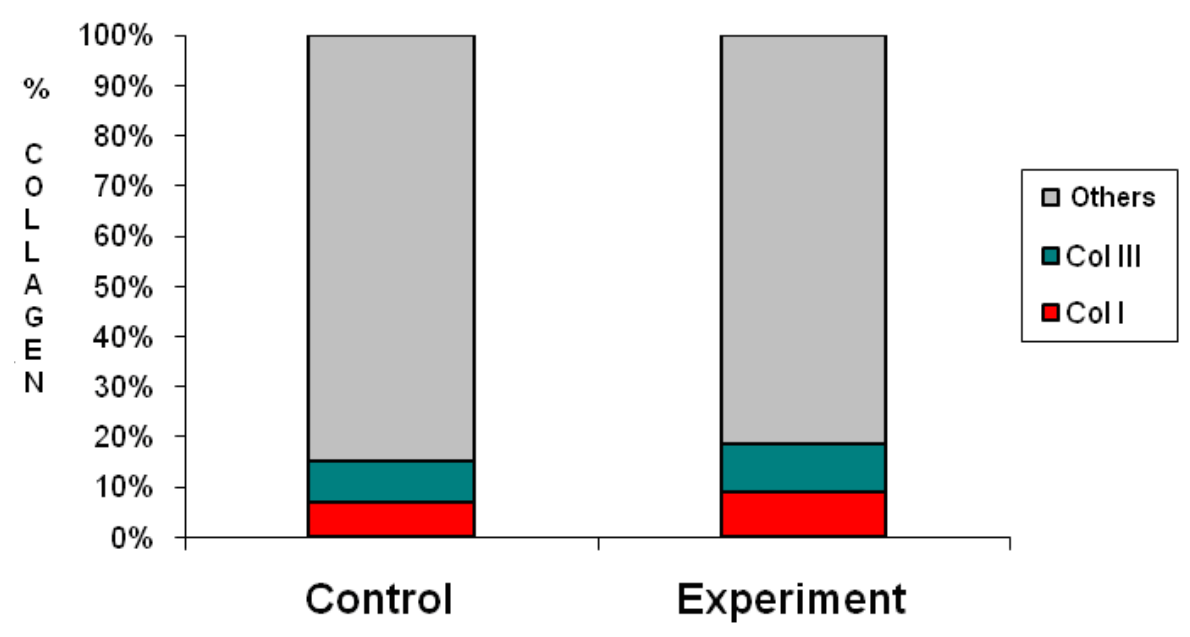

FIGURE 5 - Collagen density in the aponeurotic scars on the 7th day

On the fourteenth day, in the aponeurotic scar, there was no difference in total collagen density $(p=0.779)$, type $I(p=0.867)$

or type III collagen $(\mathrm{p}=0.779)$ (Figure 6).

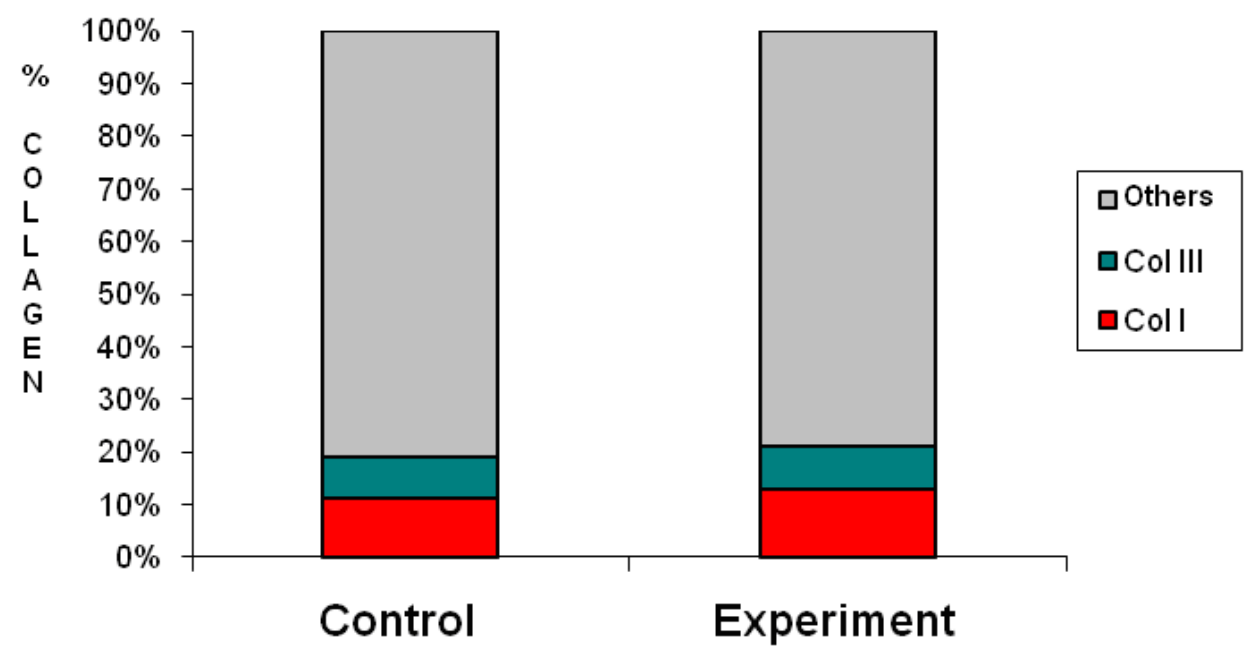

FIGURE 6 - Collagen density in the aponeurotic scars on the14th day 


\section{Discussion}

An incisional hernia is a common post-surgery complication in the obese. It is related to local, systemic and immunological factors. It occurs in approximately $10 \%$ of patients in any type of abdominal surgery and in $20 \%$ of abdominal surgery for obese patients $^{12}$. The higher rate of incisional hernia in obese patients has been related to higher intra-abdominal pressure in these patients ${ }^{12}$.

Obesity is a negative factor when it comes to healing abdominal wounds, although no experimental studies have been found that prove this. It has been shown in an experimental study on rats that skin healing was deficient when compared to rats on a normal calorie diet ${ }^{14}$.

Johson et al. ${ }^{21}$ monitored 493 patients submitted to a kidney transplant, 59 of whom were obese. They found that there was superficial dehiscence in $14 \%$ of obese patients and in $4 \%$ of nonobese patients $(p<0.01)$. There was total dehiscence of the wound in $3 \%$ of obese patients and in none of the non obese $(p<0.01)$.

Chang et al. ${ }^{22}$ followed the plastic reconstruction of the thorax of 718 patients. They found that the obese had more serious complications related to the flap $(\mathrm{p}=0.001)$, with $3,2 \%$ total loss of the flap $(p=0.001)$. They found a higher rate of seromas $(p=0.004)$, necrosis $(p=0.001)$ and infection $(p=0.016)$. Overweight patients had similar rates of complications.

Almahmeed et al. ${ }^{23}$ collected the data of 840 patients who had undergone surgical treatment for obesity. They found 36 cases of dehiscence $(4.3 \%)$. These patients showed a significantly higher rate of complication $(p<0.001)$ and mortality $(p=0.01)$, in addition to having to spend more time in hospital. Whereas the average stay in hospital for those with no anastomosis dehiscence was 4.5 days, for those with this complication, the average stay was 24.5 days $(\mathrm{p}<0.001)$. According to these authors, patients with dehiscence were 15.95 times more likely to die $(p=0.002)$. In the case of sepsis, the likelihood of death was 27.95 times higher $(p=0.02)$. In the case of kidney failure, the patient was 16.95 times more likely to die ( $\mathrm{p}=0.003$ ); in the case of thromoembolism, the patient was 9.95 times more likely to die $(p<0.001)$, and with an incisional hernia, the likelihood was 5.95 times higher $(p=0.001)$.

The difficulty of studying the healing process in patients leads to a search for an animal model in order to recognize the real influence of obesity in the healing process. In the literature, there are several obesity models, including a lesion of the hypothalamic ventromedial nucleus by administration of monosodium glutamate tonewborn rats ${ }^{24}$; oophorectomy ${ }^{25}$ and hypercaloric diets ${ }^{18,26,27,28}$.

The diet used in this study was effective in making the rats gain weight.

Among the likely factors involved in changes to the healing process in the obese are stimulation by transforming growth factor beta (TGF- $\beta 1$ and TGF- $\beta 2)^{29}$ and the platelet-derived growth factor (PDGF $)^{30}$, fibroblast adhesion to the collagen matrix and the individual links between the collagen chains ${ }^{31,32}$.

A number of authors have described excess adipose tissue as inducing the inflammatory process, possibly due to increased pro-inflammatory mediators like alpha tumor necrosis factor (TNF- $\alpha$ ) and several interleukins ${ }^{33}$. Although inflammation is important in the healing process, when it is exacerbated the process can be adversely affected. An increased inflammatory reaction has been reported as the cause of wounds not healing ${ }^{34-36}$. As the rats from the experiment group experienced increased adipose tissue, it may be assumed that they were more exposed to pro-inflammatory cytokines and should consequently be exposed to a lower inflammatory reaction than the rats in the control group. However, there were no significant differences between the two groups, leading to the hypothesis that other factors may be involved. One of these could be that the inflammatory reaction would be exacerbated in obese rats only in the early phase and, in this case, it would already have become balanced after 7 and 14 days.

The resistance of a scar is determined by a series of events, which include interactions between cells, the extracellular matrix and cytokines. During the second week of healing, the fibroblasts take on the role of myofibroblasts, and this stage is the beginning of the definitive organization of the conjunctive tissue and the contraction of the wound, factors which will influence the final resistance of the scar. In this study, there was no significant difference concerning the gain of resistance of the skin scars. Nevertheless, the aponeurotic scars gained less resistance in the obese rats. It is interesting to note that the collagen density in the cutaneous and aponeurotic scars was not signficiantly different. However, in the aponeurotic scars, after seven days, although the collagen density was similar, there was higher collagen III density in the scars in the experiment group. This type of collagen has finer and more delicate fibers, which could account for their lower resistance. The collagen synthesis is oxygen dependent, aponeuroses have little vascularization and this is also the case with adipose tissue. This may account for the difference in collagen density and the gain in resistance.

\section{Conclusion}

Obesity lowered the resistance of the aponeurotic scars but not the skin scars. It did not interfere with the delayed inflammatory response and the collagen density in rats.

\section{References}

1. WHO - World Health Organization. Obesity and overweight. Fact sheet N³11 September 2006. Disponível em [http://www.who.int/mediacentre/ factsheets/fs311/en/index.html]. Acesso em 03/03/2009.

2. Stevens VJ, Obarzanek E, Cook NR, Lee IM, Appel LJ, Smith West D, Milas NC; Mattfeldt-Beman M; Belden L, Bragg C; Millstone M, Raczynski J, Brewer A, Singh B, Cohen J, Trials for the Hypertension Prevention Research Group. Trials for the Hypertension Prevention Research Group. Long-term weight loss and changes in blood pressure: results of the Trials of Hypertension Prevention, phase II. Ann Intern Med. 2001;134(1):1-11.

3. Bult MJ, van Dalen T, Muller AF. Surgical treatment of obesity. Eur J Endocrinol. 2008;158(2):135-45.

4. Puzziferri N, Austrheim-Smith IT, Wolfe BM, Wilson SE, Nguyen NT. Three-year follow-up of a prospective randomized trial comparing laparoscopic versus open gastric bypass. Ann Surg. 2006;243(2):181-8. 5. Byrne TK. Complications of surgery for obesity. Surg Clin North Am. 2001;81(5):1181-93.

6. Livingston EH. Complications of bariatric surgery. Surg Clin North Am. 2005;85(4):853-68.

7. Nguyen NT, Goldman C, Rosenquist CJ, Arango A, Cole CJ, Lee SJ, Wolfe BM. Laparoscopic versus open gastric bypass: a randomized study of outcomes, quality of life, and costs. Ann Surg. 2001;234(3):279-89.

8. Nguyen NT, Ho HS, Palmer LS, Wolfe BM. A comparison study of laparoscopic versus open gastric bypass for morbid obesity. J Am Coll Surg. 2000;191(2):149-55. 
9. Sugerman HJ, Kellum JM, Reines HD, DeMaria EJ, Newsome HH, Lowry JW. Greater risk of incisional hernia with morbidly obese than steroiddependent patients and low recurrence with prefascial polypropylene mesh. Am J Surg. 1996;171(1):80-4.

10. Yahchouchy-Chouillard E, Aura T, Picone O, Etienne JC, Fingerhut A. Incisional hernias. I. Related risk factors. Dig Surg. 2003;20(1):3-9.

11. Bellon JM, Duran HJ. [Biological factors involved in the genesis of incisional hernia. Cir Esp. 2008;83(1):3-7.

12. Wilson JA, Clark JJ. Obesity: impediment to postsurgical wound healing. Adv Skin Wound Care. 2004;17(8):426-35.

13. Gårdlund B, Bitkover CY, Vaage J. Postoperative mediastinitis in cardiac surgery - microbiology and pathogenesis. Eur J Cardiothorac Surg. 2002;21(5):825-30.

14. Nascimento AP, Costa AM. Overweight induced by high-fat diet delays rat cutaneous wound healing. Br J Nutr. 2006;96(6):1069-77.

15. Sauerland S, Korenkov M, Kleinen T, Arndt M, Paul A. Obesity is a risk factor for recurrence after incisional hernia repair. Hernia. 2004; $8(1): 42-6$.

16. Jaworski K, Ahmadian M, Duncan RE, Sarkadi-Nagy E, Varady KA, Hellerstein MK, Lee HY, Samuel VT, Shulman GI, Kim KH, de Val S, Kang C, Sul HS. AdPLA ablation increases lipolysis and prevents obesity induced by high-fat feeding or leptin deficiency. Nat Med. 2009;15(2):159-68. 17. Ahima RS, Flier JS. Adipose tissue as an endocrine organ. Trends Endocrinol Metab. 2000;11(8):327-32.

18. Levin BE, Hogan S, Sullivan AC. Initiation and perpetuation of obesity and obesity resistance in rats. Am J Physiol. 1989;256(3):R766-71. 19. American Veterinary Medical Association. Guidelines on Euthanasia (Formerly Report of the AVMA Panel on Euthanasia). June 2007. Available from http://www.avma.org/resources/euthanasia.pdf, acesso 11 mar. 2009.

20. BRASIL. Resolução n.o 714 do Conselho Federal de Medicina Veterinária, de 20 de junho de 2002. Dispõe sobre procedimentos e métodos de eutanásia em animais e dá outras providências.

21. Johnson DW, Isbel NM, Brown AM, Kay TD, Franzen K, Hawley CM, Campbell SB, Wall D, Griffin A, Nicol DL. The effect of obesity on renal transplant outcomes. Transplantation. 2002;74(5):675-81.

22. Chang DW, Wang B, Robb GL, Reece GP, Miller MJ, Evans GR, Langstein HN, Kroll SS. Effect of obesity on flap and donor-site complications in free transverse rectus abdominis myocutaneous flap breast reconstruction. Plast Reconstr Surg. 2000;105(5):1640-8.
23. Almahmeed T, Gonzalez R, Nelson LG, Haines K, Gallagher SF, Murr MM. Morbidity of anastomotic leaks in patients undergoing Roux-en-Y gastric bypass. Arch Surg. 2007;142(10):954-7.

24. Lorden JF, Caudle A. Behavioral and endocrinological effects of single injections of monosodium glutamate in the mouse. Neurobehav Toxicol Teratol. 1986;8(5):509-19.

25. Chen Y, Heiman ML. Increased weight gain after ovariectomy is not a consequence of leptin resistance. Am J Physiol Endocrinol Metab. 2001;280(2):E315-22.

26. Naderali EK, Fatani S, Williams G. Chronic withdrawal of a high-palatable obesity-inducing diet completely reverses metabolic and vascular abnormalities associated with dietary-obesity in the rat. Atherosclerosis. 2004;172(1):63-9.

27. Lima-Leopoldo AP, Sugizaki MM, Leopoldo AS, Carvalho RF, Nogueira CR, Nascimento AF, Martinez PF; Luvizotto RA; Padovani CR; Cicogna AC. Obesity induces upregulation of genes involved in myocardial Ca2+ handling. Braz J Med Biol Res. 2008;41(7):615-20.

28. Nascimento AF, Sugizaki MM, Leopoldo AS, Lima-Leopoldo AP, Luvizotto RA, Nogueira CR, Cicogna AC. A hypercaloric pellet-diet cycle induces obesity and co-morbidities in Wistar rats. Arq Bras Endocrinol Metabol. 2008;52(6):968-74.

29. Montesano R, Orci L. Transforming growth factor beta stimulates collagen-matrix contraction by fibroblasts: implications for wound healing. Proc Natl Acad Sci USA. 1988;85(13):4894-7.

30. Clark RA, Folkvord JM, Hart CE, Murray MJ, McPherson JM. Platelet isoforms of platelet-derived growth factor stimulate fibroblasts to contract collagen matrices. J Clin Invest. 1989;84(3):1036-40.

31. Schiro JA, Chan BM, Roswit WT, Kassner PD, Pentland AP, Hemler ME, Martinez PF, Luvizotto RA, Padovani CR, Cicogna AC. Integrin alpha 2 beta 1 (VLA-2) mediates reorganization and contraction of collagen matrices by human cells. Cell. 1991;67(2):403-10.

32. Woodley DT, Yamauchi M, Wynn KC, Mechanic G, Briggaman RA. Collagen telopeptides (cross-linking sites) play a role in collagen gel lattice contraction. J Invest Dermatol. 1991;97(3):580-5.

35. Garner WL, Karmiol S, Rodriguez JL, Smith DJ, Jr., Phan SH. Phenotypic differences in cytokine responsiveness of hypertrophic scar versus normal dermal fibroblasts. J Invest Dermatol. 1993;101(6):875-9. 36. Cooney R, Iocono J, Maish G, Smith JS, Ehrlich P. Tumor necrosis factor mediates impaired wound healing in chronic abdominal sepsis. J Trauma. 1997;42(3):415-20.

Conflict of interest: none Financial source: none

\section{Correspondence:}

Maria de Lourdes Pessole Biondo-Simões

Rua Ari José Valle, 1987

82030-000 Curitiba - PR Brazil

Phone (55 41)3297-4359/3223-4637/9991-5566

biondo@avalon.sul.com.br

\section{How to cite this article}

Biondo-Simões MLP, Zammar GR, Fernandes RS, Biondo-Simões R, Mello FSR, Noronha L. Obesity and abdominal wound healing in rats. Acta Cir Bras. [serial on the Internet] 2010 Jan-Feb;25(1). Available from URL: http://www.scielo.br/acb 